\title{
Factors Influencing Municipal Solid Waste Generation and Composition in Kathmandu Metropolitan City, Nepal
}

\author{
Raju Khadka*, Majeed Safa*, Alison Bailey*, Birendra KC**, Raju Poudel*** \\ *Department of Land Management and Systems, Lincoln University, New Zealand \\ **aqualinc research limited, Christchurch, New Zealand \\ **Vyas Municipality Office, Tanahun, Nepal \\ DOI: 10.29322/IJSRP.11.01.2021.p10961 \\ http://dx.doi.org/10.29322/IJSRP.11.01.2021.p10961
}

\begin{abstract}
Increasing metropolitan solid waste and absence of concrete information sources is a developing worry in urban areas of developing countries like in Kathmandu Metropolitan City (KMC) in Nepal. Two goals of this study were: (1) to estimate household solid waste generation and its composition; and (2) to assess the socioeconomic factors impacting on household waste generation. Using stratified sampling, 288 families were chosen from the 32 wards of KMC for household survey. The quantification of total waste and its composition was undertaken for each household using digital weighing scales. Socioeconomic variables affecting household waste generation were analysis by using regression model. The rate of household waste generation in KMC was found $0.3 \mathrm{~kg} / \mathrm{capita} / \mathrm{day}$ and total household waste generation was found 413 tonnes/day. Household waste comprised of $51 \%$ organic and $49 \%$ recyclable comprising $5 \%$ paper and paper products, $3 \%$ glass, $1 \%$ metal, $19 \%$ plastic, $13 \%$ textiles, $4 \%$ rubber and leather and $4 \%$ other waste. As organic waste constitutes more than half proportion of total solid waste, it should deal appropriately, if not it will create serious health and environmental hazards. Household size and income had a positive impact on waste generation; both were statistically significant and thus are important indicators in forecasting solid waste generation trends. Finding from this study will help concerning authority to formulate sustainable solid waste management plan in KMC and beyond.
\end{abstract}

Index Terms- Household, Waste generation, waste composition, Kathmandu Metropolitan City, socioeconomic factors

\section{INTRODUCTION}

Population growth coupled with rapid urbanization is one of the main issues worldwide, creating increased generation of solid waste per unit area [1]. Urbanization and fast financial development of urban communities improve socioeconomic status of the population leading to more food consumption and thus more waste generation [2]. A World Bank report 2012 highlighted that the amount of municipal solid wastes (MSW) of cities around the world might reach 2.2 billion tonnes per year by 2025 and waste generation rates might double over the next two decades in developing countries [3]. Trang, Dong [4] identified a correlation between socio-economic factors and household waste generation. It showed that income has a negative significant effect whereas household size has a positive impact on household waste generation.

Bandara, Hettiaratchi [5] indicated that socio-economic factors, e.g., age, income, and education level, contributed to variations in household waste generation. [2,6] found that an income expansion could change the consumption patterns of households, causing changed composition and amounts of household waste. Increased family size and the improved dietary patterns have positive relationships with waste generation [7]. [8] showed that the quality and quantity of the generated waste were different in various economic and income groups. Moreover, there was a critical, positive relationship between family size and waste per capita.

Urban and semi-urban areas of emerging and least developed countries are particularly facing great challenges in the management of solid waste [1, 9]. Emerging and least developed groups of countries are identified on three criteria: I) income; II) access to human resources; and III) economic vulnerability [10]. About $60 \%$ of the world's population live in Asia where the quantity of waste generated has increased; the rates of waste generation in the least developed countries are lower than those of developed countries [11, 12]. Visvanathan, Trankler [13] stated that urban population growth, unplanned urbanization and increased economic activity and resource consumption are the main causes of increasing Municipal Solid Waste (MSW) generation in Asian Countries. However, prevailing solid waste management (SWM) systems are not satisfactory. 
In South Asia region, around 426 million people live in urban areas and produce roughly 70 million tonnes of waste each year, with per capita production running from 0.12 to $5.1 \mathrm{~kg}$ per day and a normal of $0.45 \mathrm{~kg}$ day per day [14]. The standard of living leads to a higher consumption of products and, potentially, greater waste generation [15]. Figure 1 illustrates waste generation rates in some Asian countries. As can be seen, Asian emerging countries will significantly increase waste generation rates by 2025 .

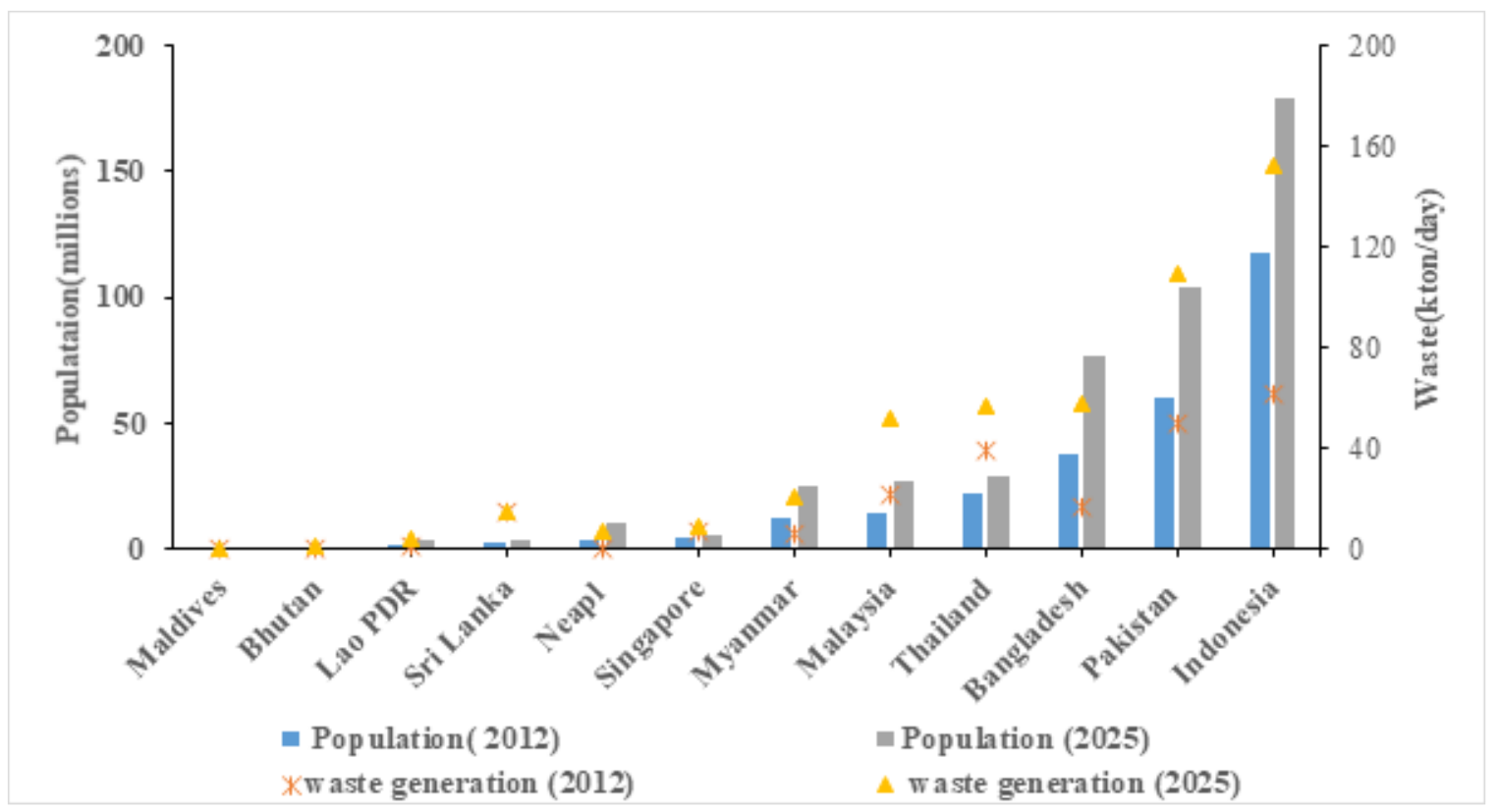

Figure 1. Total population \& waste generation in the selected Asian countries in 2012 and2025 (3)

MSW consists, to a large extent, of organic and other biodegradable matter; the non-biodegradable matter is dirt, ash and another household rubbish [16]. Figure 2 compares the waste composition and per capita waste generation in Asian countries [3]. It is observed that the MSW in most of the Asian countries is mainly composed of organic waste with an average of around 56\%, followed by other $(10 \%)$, paper $(12 \%)$, plastic $(5 \%)$, and glass and metal $(1 \%)$ on average.

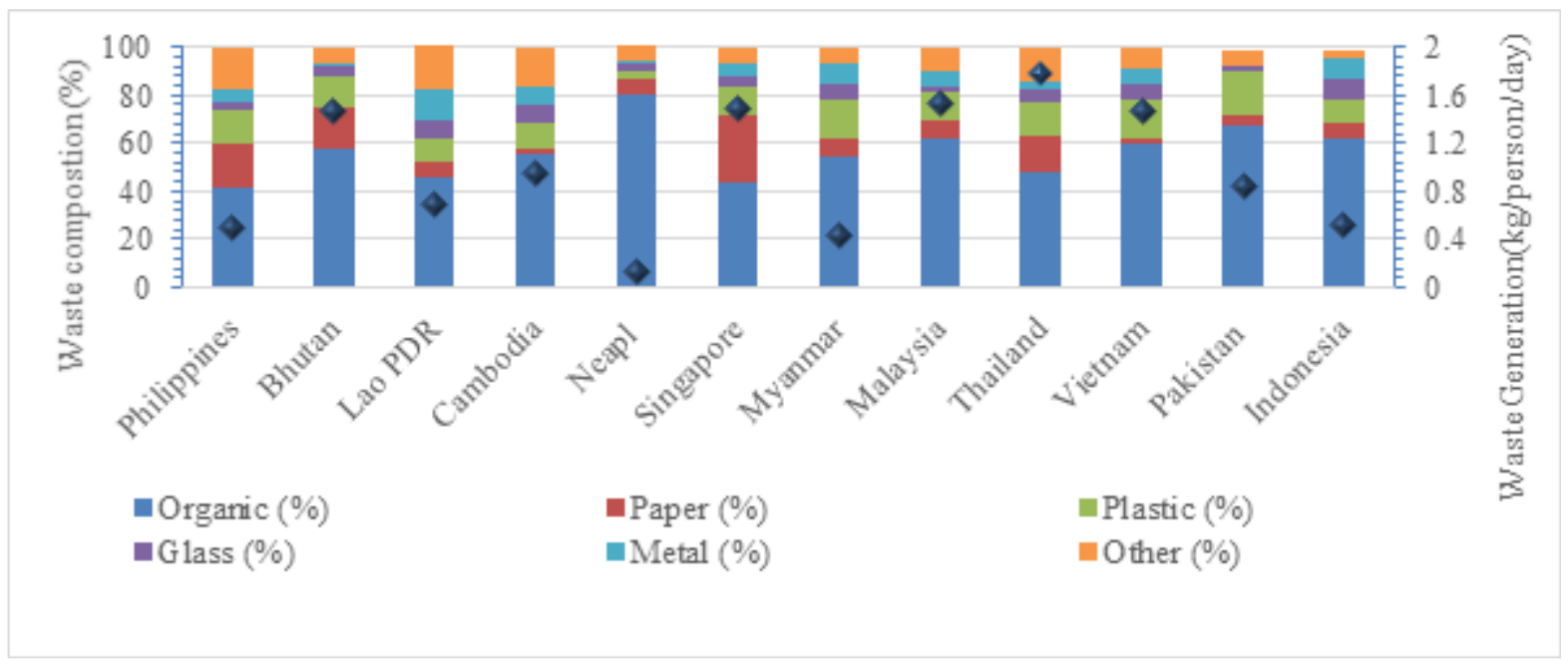

Figure 2: Comparison of waste composition and waste generation (kg/person/day) in selected Asian countries [3]

Organic matter generally accounts for $50 \%-80 \%$ of MSW in developing Asian countries as shown in Table 1 . The degree of decomposable waste in MSW in Nepal is identical with neighboring nations and nations of the similar financial status; it contains a higher extent of plastics. Nepal's composition being $80 \%$ organic is higher than upper-middle-income countries [3]. 
The least developed countries in Asia, such as Nepal, are facing environmental problems because of rapid and uncontrolled urbanization, and a lack of public awareness regarding proper Solid Waste Management [17]. The volume of waste and its composition in Nepal depends on different variables including urbanization, people's living standards, population growth and economic activities [17]. These issues need to be addressed during the formulation of Municipal Solid Waste Management (MSWM) plan.

Table 1: A comparison of waste composition (\%) and GDP per capita in selected Asian countries

\begin{tabular}{lcllllll}
\hline Country & GDP Per Capita & Organic (\%) & Paper (\%) & Plastic (\%) & Glass (\%) & Metal (\%) & Other (\%) \\
\hline Nepal & 730 & 80.0 & 7.0 & 2.5 & 3.0 & 0.5 & 7.0 \\
Bangladesh & 1,190 & 70.0 & 4.0 & 5.0 & 1.0 & 2.0 & 18.0 \\
India & 1,590 & 42.0 & 6.0 & 4.0 & 2.0 & 3.0 & 43.0 \\
Vietnam & 1,980 & 58.0 & 4.0 & 4.0 & 1.6 & 1.5 & 30.9 \\
Indonesia & 3,440 & 74.0 & 10.0 & 8.0 & 2.0 & 2.0 & 4.0 \\
Philippines & 3,540 & 41.6 & 19.5 & 13.8 & 2.5 & 4.8 & 17.8 \\
Sri-Lanka & 3,800 & 76.4 & 10.6 & 5.7 & 1.3 & 1.3 & 4.7 \\
Thailand & 5,620 & 48.0 & 15.0 & 14.0 & 5.0 & 4.0 & 14.0 \\
China & 7,820 & 35.8 & 3.7 & 3.8 & 2.0 & 0.3 & 54.4 \\
Malaysia & 10,570 & 40.0 & 15.0 & 15.0 & 4.0 & 3.0 & 23.0 \\
Singapore & 52,600 & 44.0 & 28.0 & 12.0 & 4.0 & 5.0 & 7.0 \\
\hline
\end{tabular}

Sources: [18]

Municipal household waste is often generated from several sources since variable human activities are encountered. In Nepal, households represent, on average, $75 \%$ of total municipal waste generation [19]. Solid waste is not a new issue because humans have always produced and managed rubbish in some way, but current concern is the change in amount and type of waste produced and methods for its management [20]. Kathmandu Metropolitan City (KMC) has confronted incredible difficulty in solid waste management including the collection, transport, and disposal of waste. There is also an absence of public consciousness on solid waste management, unplanned urbanization, changing lifestyle and people's consumption patterns and the presentation of environmentally unpleasant materials. To address the issues, this study assessed MSW generation and its composition in KMC. In addition, the study assessed the socio-economic factors affecting waste generation and waste composition in KMC.

\section{Municipal Solid Waste Situation in KMC}

The problem of solid waste management in the municipalities on the outskirts of the Kathmandu Valley is not as severe as in the municipalities inside the valley. Kathmandu Valley occupies only about $0.5 \%$ of the total land area of Nepal but it has $10 \%$ of population. Therefore, the management of solid waste and the challenges experienced by the municipalities in Kathmandu valley are greater than for elsewhere [21].

In 1990, with financial support from German Technical Cooperation Agency, the municipalities started to work with the Solid Waste Management and Resource Mobilization Center (SWMRMC), a government body under the Ministry of Local Development, collecting, transporting to landfill, and partly recycling waste. In 1995, the municipalities took full responsibility when SWMRMC closed all its activities in waste management [22]. Solid waste management in the Kathmandu Valley, particularly the foundation of a landfill site, has been a test for well longer than 10 years. The current practice of the illegal dumping of solid waste on riverbanks has created a serious environmental and public health problem. The data show that $70 \%$ of the solid wastes generated in Nepal are of organic origin [21].

Because of rapid urbanization, KMC is facing an increasing rate of MSW generation. From 2001 to 2011, population in KMC increased by $4.76 \%$ per year [23]. During the same time Period waste generation increased by 5.36\% per year [24].This has created unprecedented stress on the city's limited resources and infrastructure creating MSW management problems [24]. Different studies have shown that solid waste generation in urban areas varies from one municipality to another, ranging from $0.25 \mathrm{~kg} / \mathrm{capita} / \mathrm{day}$ to $0.5 \mathrm{~kg} / \mathrm{capita} / \mathrm{day}$ with an average of $0.37 \mathrm{~kg} / \mathrm{capita} / \mathrm{day}$ [25]. According to Dangi, Pretz [24], the average household waste generation in KMC was around 0.5 $\mathrm{kg} / \mathrm{person} /$ day based on the population of 750,597 during late 2010. According to a previous MSW generation and composition study in KMC, the MSW generated in households was about $0.38 \mathrm{~kg} / \mathrm{capita} / \mathrm{day}$ [26]. 
Solid waste management (SWM) services have consistently failed to keep up with the vast amount of solid waste produced in urban areas. There is no current efficient system in place for the management, storage, collection, and transport of solid waste [27]. Teku transfer station is utilized for collection of waste and no recycling alternatives are executed here. Primary and secondary collection systems are available for collecting waste from houses in KMC. In primary collection, individual households place their raw solid waste into personal refuse bins that are then transferred to the transfer station or landfill site by KMC. In secondary collection, solid waste is collected from roadsides or containers and transported to the transfer station or final disposal site [27]. Studies by SWMRM [28], ADB [17] and Dahal [26] compared the amount of waste generated and its composition in KMC with the national average (see in table 2 and 3)

Table 2: A comparison of KMC's municipal solid waste generation with the national municipal average

\begin{tabular}{|c|c|c|c|c|c|c|}
\hline & 2003 & & 2008 & & 2013 & \\
\hline Variables & Nepal Average & $\mathrm{KMC}$ & Nepal Average & $\mathrm{KMC}$ & Nepal Average & KMC \\
\hline $\begin{array}{l}\text { Household waste } \\
\text { generation } \\
\text { (kg/person/day) }\end{array}$ & 0.25 & 0.39 & 0.27 & 0.38 & 0.17 & 0.23 \\
\hline $\begin{array}{l}\text { Total waste } \\
\text { generation } \\
\text { (Tonnes/day) }\end{array}$ & 23.60 & 300.00 & 19.89 & 336.00 & 24.74 & 466.14 \\
\hline $\begin{array}{l}\text { Total waste collection } \\
\text { (Tonnes/day) }\end{array}$ & 11.79 & 250.00 & 13.05 & 306.00 & 18.27 & 405 \\
\hline $\begin{array}{l}\text { Collection Efficiency } \\
(\%)\end{array}$ & 49.95 & 83.00 & 65.61 & 91.00 & 73.85 & 86.90 \\
\hline
\end{tabular}

SWMRM [28], ADB [17] and Dahal [26]

Table 3: A composition comparison of the municipal solid waste of $\mathrm{KMC}$ with the national municipal average

\begin{tabular}{|c|c|c|c|c|c|c|}
\hline \multirow{2}{*}{$\begin{array}{l}\text { Waste Composition } \\
(\%)\end{array}$} & \multicolumn{2}{|l|}{2003} & \multicolumn{2}{|l|}{2008} & \multicolumn{2}{|l|}{2013} \\
\hline & $\begin{array}{l}\text { Nepal } \\
\text { Average (\%) }\end{array}$ & $\begin{array}{l}\text { KMC } \\
(\%)\end{array}$ & $\begin{array}{l}\text { Nepal } \\
\text { Average (\%) }\end{array}$ & $\begin{array}{l}\text { KMC } \\
(\%)\end{array}$ & $\begin{array}{l}\text { Nepal } \\
\text { Average (\%) }\end{array}$ & $\begin{array}{l}\text { KMC } \\
(\%)\end{array}$ \\
\hline Organic & 62.00 & 67.00 & 61.30 & 68.00 & 66.20 & 64.24 \\
\hline Plastic & 7.30 & 16.00 & 8.40 & 13.00 & 12.00 & 15.96 \\
\hline $\begin{array}{l}\text { Paper and paper } \\
\text { products }\end{array}$ & 8.20 & 10.00 & 8.60 & 10.00 & 9.00 & 8.66 \\
\hline Glass & 2.40 & 1.00 & 4.10 & 4.00 & 3.10 & 3.75 \\
\hline Metal & 1.20 & 1.00 & 1.30 & 1.00 & 1.90 & 1.72 \\
\hline Textile & 1.90 & 4.00 & 1.70 & 1.00 & 2.20 & 3.40 \\
\hline $\begin{array}{l}\text { Rubber and } \\
\text { Leather }\end{array}$ & 0.90 & 0.24 & 1.10 & 1.00 & 1.10 & 1.12 \\
\hline Others & 16.10 & 0.24 & 13.50 & 1.00 & 4.50 & 1.15 \\
\hline
\end{tabular}

SWMRM [28], ADB [17] and Dahal [26]

\section{RESEARCH METHODOLOGY}

\section{Study area}

The study area, Kathmandu Metropolitan City ( $85^{\circ} 20^{\prime}$ East and $27^{\circ} 42^{\prime}$ north), lies in the Kathmandu Valley, Nepal. It covers an area of $50.67 \mathrm{~km} 2$. The elevation of Kathmandu is 1,350 meters above mean sea level [29]. The Kathmandu Valley has a mild climate most 
of the year with summer temperatures ranging from $19-27^{\circ} \mathrm{C}$ and winter temperatures ranging from $2-20^{\circ} \mathrm{C}$. Total annual rainfall in the area is $1,505 \mathrm{~mm}[30]$.

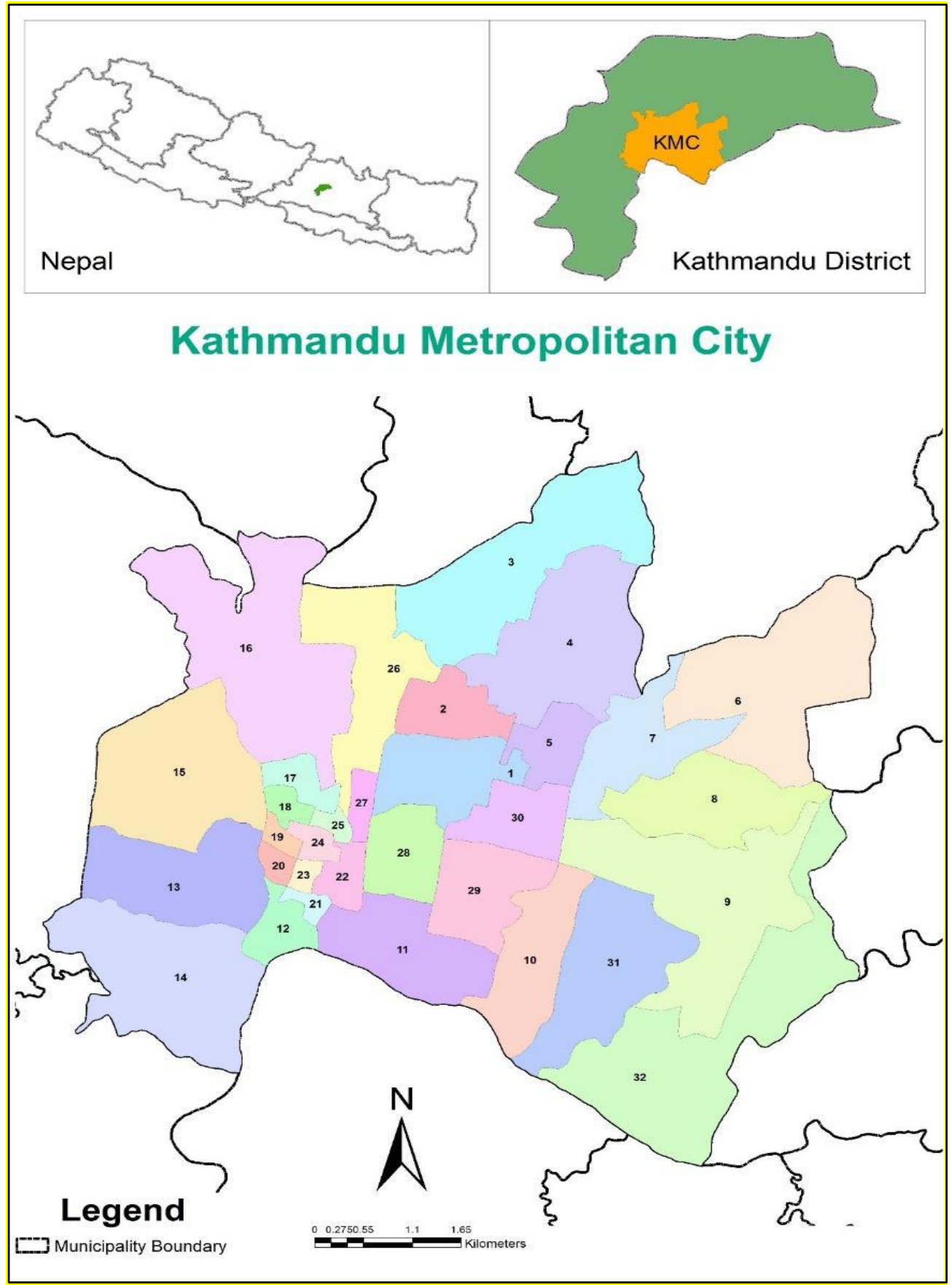

Figure 3: Study area, Kathmandu, Nepal [31]

In the last 20 years, the population of the city has grown at an annual growth rate of 4.82\% from 671,846 in 2001 to 1,006,656 in 2011 [32]. The total number of households in KMC is 154,302. There are 32 wards in KMC (see Figure 3), and, of them, the maximum population is in ward 16 with 84,441 people and 22,715 household as shown in figure 3 . The minimum population is in ward 26 with 4,133 people and 947 households. The population density of KMC is 20,289 people per $\mathrm{km} 2$ [32] and the average household size is 3.94, which is below the national average of 4.21 [33]. Because of rapid population growth and urbanization, the quantity of waste generated in Kathmandu city is increasing rapidly so demanding attention for proper SWM. 


\section{Household Survey}

This study relies on primary data gathered from individual households, because, in Nepal, household waste is responsible for about $75 \%$ of total municipal waste [34]. A survey approach that incorporates two or more survey methods to collect data, termed a mixed mode survey method, was used in this study [35]. The mixed-mode survey method used for this study consisted of first distributing copies of the questionnaire, so households were aware of the questions, and then completing the survey by asking the questions directly in their house. The questionnaire was prepared to target waste management practices by households, seeking specific answers, therefore, a faceto-face interview was the most appropriate approach for the survey.

The questionnaire was distributed to 300 households whose physical addresses were obtained from KMC. It asked householders to take part in the survey. KMC is a city level environmental body focused on addressing the challenges and opportunities of the city solid waste sector in the city. A total of 288 households agreed to be surveyed and were interviewed between November 2019 and July 2020.

The questionnaire was developed step by step by consulting with several scientists, relevant experts at Lincoln University, and other organizations including Christchurch Waste Management, Aqualinc Research Limited New Zealand and the Solid Waste Resources Mobilization Centre, Nepal, before conducting the final survey. The survey questionnaire was pre-tested on some selected households. The pre-test survey data (pilot study) were not included in the final data set. To conduct the survey, approval was received from the Human Ethics Committee, Lincoln University, Christchurch, New Zealand. Before conducting survey, consent was obtained from the person who was responsible for household management (household head).

This household survey used a semi-structured questionnaire. The questionnaire included the personal information (e.g., age, education level and income) of the oldest person in each surveyed household along with other questions to obtain information on total daily waste generation, its composition and collection method. The questionnaire was designed to find any relationship between waste generation and various variable such as income, family size, education level, age, because various studies, e.g., Maskey, Maharjan [34], have suggested that waste generation activities vary with those variables. The quantification of total waste and its composition was undertaken for each household using digital weighing scales.

For reliability and to find the overall situation for the population, Equation 1 was used to compute the sample size. The formula is applicable for populations of 10,000 or more [36]:

$$
\mathrm{n} \geq \frac{p(1-p) Z^{2}}{d^{2}}
$$

where: $\mathrm{n}$ is the minimum sample size; $\mathrm{z}$ is the value from the standard normal distribution, (1.645 with a $90 \%$ level of confidence); $\mathrm{p}$ is the expected probability it affects in a community larger than 10,000; and $\mathrm{d}$ is the maximum allowable deviation or estimate error, i.e., $\pm 5 \%$ precision. Based on the formula, the minimum sample size required for this study was 227 . Each household had an equal opportunity to be chosen in the study to ascertain the representative views.

\section{Data Analysis}

All completed questionnaires were coded before the results were entered into a spreadsheet database. Data processing and analysis were done with Excel software. Statistical tools such as number, percentage, mean, standard deviation, regression model, average and ratios, were used to interpret the findings. The variables used in this study are discussed below.

\section{Family Size}

Household size $(\mathrm{HH})$ is correlated with waste generation because of its influence on eating and consumption habits [37]. In this study children less than 10 years old are not consider. In this study children less than 10 years old are not consider. For waste generation, the results show that household waste generation is significantly affected by household size. Changes in household living patterns and demographic attributes impact waste generation. Household size is directly linked to waste generation with larger households naturally producing more waste $[5,38,39]$. Bureecam and Chaisomphob [40] found that population density, the household size and the size of the municipality were the significant factors determining the MSW generation rate in Thailand. For the Philippines, Jenkins [41] 
indicated that smaller households produced more waste per capita whereas Cailas, Kerzee [42], [43] found no effect in Illinois, USA. This study intends to see the impact of household size on waste generation.

\section{Age}

Kayode and Omole [44] found a negative impact of age in Nigeria; older people produced less waste, whereas Maskey, MAHARJAN [34] found the age of household's oldest person had a significant positive relationship with waste generation in the Philippines. In emerging countries, Jenkins [41] highlighted a positive correlation between waste generation and age. Richardson and Havlicek Jr [45] indicated that those who were middle aged rather than young or old produced more waste. This variable is to see if there is a relationship between age and waste generation.

\section{Education}

Education potentially plays a key role in a household's decision on how to manage its waste. Higher education has been associated with lower waste generation [46] and with an increase in separation and recycling [47];[48];[49];[50];[51]. Kayode and Omole [44] found a positive influence of educational status on waste generation. Sujauddin, Huda [52] showed a positive impact of education on waste generation in Bangladesh. This study considers household education as the education level of the oldest person in the family to investigate any relationship between education and waste generation.

\section{Income}

Various studies have shown how socio-economic parameters affect household waste generation. There is evidence that higher income households generate more waste $[5,53,54]$ ). This study considers household income as the income of the oldest person in the family. This variable is to test any relationship between income and waste generation.

Multiple linear regression was used to investigate a correlation between household waste and family member. It is a set of techniques to study straight-line relationships among two or more variables [55]. A simple model with the highest $\mathrm{R}^{2}$ can be designed through a combination of forward, backward, and stepwise regression adjustments. Terms are always maintained in the final model if they were significant at $\mathrm{p}=0.05$. The first step, the relationship between waste generation and each input variable, was tested with simple linear regression using the $\mathrm{R}^{2}$ as the decision criterion. A multiple linear regression model was then developed for predicting waste generation as:

$$
\mathrm{Y}=\mathrm{x} 0+\mathrm{x} 1 \mathrm{M} 1+\mathrm{x} 2 \mathrm{M} 2+\ldots+\mathrm{xnMn}+\epsilon \quad \mathrm{Eq}[2]
$$

where: $\mathrm{Y}$ is the total amount of household waste generated and $\mathrm{x} 0$ - is coefficient of intercept, $\mathrm{M} 1-\mathrm{Mn}$ are the independent variables (household socioeconomic factors) and $\epsilon$ is the error [56]. The model is in a linear form to represent linear relationships between the dependent and the independent variables and the interactions between the independent variables. Their description and measurement units are shown in Table 4.

Table 4: A description and units of measurement of selected continuous variables of waste generation and household head

\begin{tabular}{llc} 
Variable & Description & Measurement unit \\
\hline Household waste & Solid waste generation by the household & $\mathrm{kg} / \mathrm{day}$ \\
Age & Oldest person of household head & Years \\
Education & Educational attainment of Household head & Years \\
Household size & Total number of family members & Number \\
Income & Total monthly income of Household head & USD \\
\hline
\end{tabular}

\section{Model validation}

A model is considered valid if it reproduces the outcomes. To measure model legitimacy from a stochastic viewpoint, specialists have proposed different statistical induction methods, for example, $\chi 2$ test on residuals among model and test results [57]. In addition, model 
validations are frequently based on comparison between the output from deterministic simulations and output from single or repeated experiments [58]. [58] categorized model validation approaches as either subjective comparisons of x-y plots, showing the trend in data over time and space or quantitative comparisons of model outputs and experimental observations. In Fakruddin, Mazumder [59] the assurance of coefficient $\left(R^{2}\right)$ can be utilized to assess the model's goodness of fit. The higher the value $\left(0<R^{2}<1\right)$, the better is the result from the model.

\section{RESULTS AND DISCUSSIONS}

\section{Socio-Economic and Demographic Characteristics of Sample Households}

This study investigated a diverse sample of households with different socio-economic and demographic characteristics. The sociodemographic features of the respondents include age, sex, educational level, work status, average monthly income, and household size.

Table 5: Socio-economic and demographic characteristics of respondents

\begin{tabular}{|c|c|c|c|}
\hline Characteristic & Category & Frequency & Percent \\
\hline \multirow{3}{*}{ Sex } & Female & 73 & 25.3 \\
\hline & Male & 215 & 74.7 \\
\hline & Total & 288 & 100 \\
\hline \multirow{6}{*}{ Age } & $29-40$ & 36 & 12.5 \\
\hline & $40-50$ & 106 & 36.8 \\
\hline & $50-60$ & 103 & 35.8 \\
\hline & $70-80$ & 40 & 13.9 \\
\hline & above 80 & 3 & 1.0 \\
\hline & Total & 288 & 100.0 \\
\hline \multirow{6}{*}{ Educational status } & No Formal education & 1 & 0.3 \\
\hline & 1-8 Primary education & 94 & 32.6 \\
\hline & 9-12 secondary education & 71 & 24.7 \\
\hline & 16-17 Higher education & 121 & 42.0 \\
\hline & Above Higher education & 1 & 0.3 \\
\hline & Total & 288 & 100.0 \\
\hline \multirow{5}{*}{ Family size } & 1-3 member & 66 & 22.9 \\
\hline & 4-6 member & 152 & 52.8 \\
\hline & 7-9 member & 62 & 21.5 \\
\hline & 10 and above & 8 & 2.8 \\
\hline & total & 288 & 100 \\
\hline \multirow{9}{*}{ Employment Status } & Agriculture & 10 & 3.5 \\
\hline & Business & 77 & 26.7 \\
\hline & Government sector & 74 & 25.7 \\
\hline & Foreign employment & 13 & 4.5 \\
\hline & Private Employee & 27 & 9.4 \\
\hline & Unskilled (Daily wage basis) & 14 & 4.9 \\
\hline & Unemployed & 29 & 10.1 \\
\hline & Other & 44 & 15.3 \\
\hline & Total & 288 & 100.0 \\
\hline \multirow{4}{*}{ Average Monthly Income } & below $\$ 100$ & 10 & 3.5 \\
\hline & $\$ 100-\$ 600$ & 84 & 29.2 \\
\hline & $\$ 600-\$ 1000$ & 70 & 24.3 \\
\hline & $\$ 1000-\$ 2000$ & 99 & 34.4 \\
\hline
\end{tabular}


above $\$ 2000$

Total
25

8.7

288

100.0

Socio-demographic characteristics of a given population have their own implications and connections with solid waste generation in a specific place particularly if they immediately reflect in the amount and composition of solid waste in specific urban areas. Table 5 presents the family and population results of the sampled household. results of the sampled households. At the $90 \%$ confidence level and $\pm 5 \%$ precision, the minimum required sample was 227 households (HHs). Therefore $227 \mathrm{HHs}$ plus an additional $20 \%$ as a precaution against any shortcomings of non-responses and/or partly filled questionnaires, giving a total $288 \mathrm{HHs}$ that were selected from 32 different wards.

Since waste storage and separation determine the feasibility of recycling and composting in a financially and environmentally sustainable manner, it assumes a crucial part in the MSWM framework. Therefore, the respondents were posed an important question concerning their understanding of and habits in segregating solid waste. Two hundred and eighty-eight households, 97.9 percent, of the sampled households disclosed their habits; only $6 \mathrm{HHs}$ ( 2.1 percent) of the respondents did not respond to question. Among those who responded to this question, 92.0 percent $(264 \mathrm{HHs}$ ) said they were willing to separate organic waste from non-decomposable, only 5.9 percent (17 $\mathrm{HHs}$ ) stated that they are not willing to separate as shown in Table 6.

Table 6: Households willing to segregate their waste at the source

\begin{tabular}{llll}
$\begin{array}{l}\text { Are you willing to segregate the } \\
\text { waste at the source? }\end{array}$ & Number & Percentage & Cumulative Percent \\
\hline Yes & 265 & 92.0 & 92.0 \\
No & 17 & 5.9 & 97.9 \\
Do not know & 6 & 2.1 & 100.0 \\
Total & 288 & 100.0 &
\end{tabular}

In Kathmandu, the private sector has already taken a keen interest in solid waste management and has established a viable business model for waste management that has a key role in every step of the process by implementing rules, regulations and principles; the sector has benefited from this. Based on this, the sampled households were asked about paying a fee for an SWM service by a service provider. Table 7 shows that 92.4 percent of the respondents said they would pay a service fee for the SWM service; 3.8 percent reported that they would not pay, and 3.8 percent did not respond to question.

Table 7: Number of households who pay fee for waste management service

\begin{tabular}{llll}
$\begin{array}{l}\text { Do you pay a fee for waste } \\
\text { management in your locality? }\end{array}$ & Number & Percentage & Cumulative Percent \\
\hline Yes & 266 & 92.4 & 92.4 \\
No & 11 & 3.8 & 96.2 \\
Do not know & 11 & 3.8 & 100.0 \\
Total & 288 & 100.0 & \\
\hline
\end{tabular}

\section{Waste Generation}

The per capita waste generation of each household was calculated by dividing the total waste produced by the number of people living in that household on sample collection day. The relationships between waste amount and various influential factors are summarized in Table 8. Household size varied from 1 to 13 with an average of 5.4. Household waste ranged between 0.2 and $3.8 \mathrm{Kg}$ per day, with an average of $1.6 \mathrm{~kg}$. This amounts to an average household waste generation of $0.3 \mathrm{~kg} / \mathrm{capita} / \mathrm{day}$ was higher than that of the other 58 municipalities of Nepal. However, it was close to the cities of other south Asia countries [60]. For the population of 2019 $(1,376,000)$, 
it has been estimated that 413 tonnes of household waste per day will be generated in Kathmandu Municipality. It can be said that waste has increased by $77.77 \%$ since 2013 [17] to 2019.

The correlation result shows that all demographic factors are positively correlated to MSW generational as shown in Table 8. It can be observed that these factors are also inter-correlated. However, household size is the strongest factors, which can be used to predict waste generation in the absence of others.

Table 8: Waste generation factor correlation coefficient

\begin{tabular}{llllll}
\hline & HH Size & Income & Education & Age & Waste \\
\hline Household size & 1 & & & & \\
Income & 0.009 & 1 & & & \\
Education & -0.046 & -0.019 & 1 & 1 & \\
Age & $.204^{* *}$ & 0.105 & -0.052 & $.183^{* *}$ & 1 \\
Waste & $.921^{* *}$ & -0.034 & $-.123^{*}$ & & \\
\hline
\end{tabular}

Table 9 shows that the household waste generation rate went up with larger families, whilst the per capita waste generation rate decreased with an increase in family size.

Table 9: Description of continuous variable result summary

\begin{tabular}{llllll}
\hline Variable & Sample Size & Mean & $\begin{array}{l}\text { Standard } \\
\text { Deviation }\end{array}$ & Min & Max \\
\hline HH waste (per capita per day) & 288 & 0.3 & 0.06 & 0.07 & 0.62 \\
HH waste (kg per day) & 288 & 1.58 & 0.76 & 0.20 & 3.8 \\
Age (Year) & 288 & 49.53 & 10.10 & 29.00 & 85 \\
Education (Year) & 288 & 10.93 & 5.40 & 1.00 & 19 \\
HH size (No) & 288 & 5.13 & 2.15 & 1.00 & 13 \\
Income*(USD) & 288 & 9,32 & 6,29 & 57 & 2,201 \\
\hline
\end{tabular}

Note. $*$ Income is in USD. 1 U.S. Dollar = 114.05 Nepalese rupees (Nepal Rastra Bank, 2020)

Figure 4 show the results from the multiple regression model. An $\mathrm{R}^{2}$ value at 0.86 confirms of the good fit of the model. It indicates that $85.67 \%$ of total variation in per day household waste generation is accounted for by four of the independent variables in the model. Among the tested variables only family size significantly affected waste generation. The other variables had a minimum effect on waste generation. This is similar to a previous study by Maskey and Singh [19]. Afroz, Masud [61] also indicated that the more members in a household, the more will be purchased and consumed that will ultimately result in higher waste generation. 


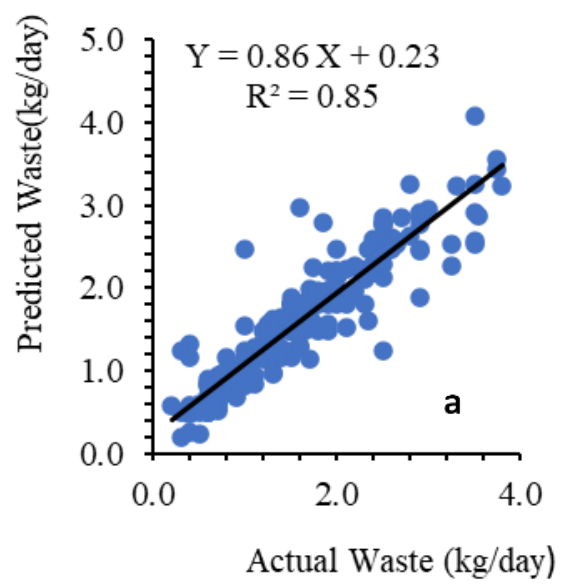

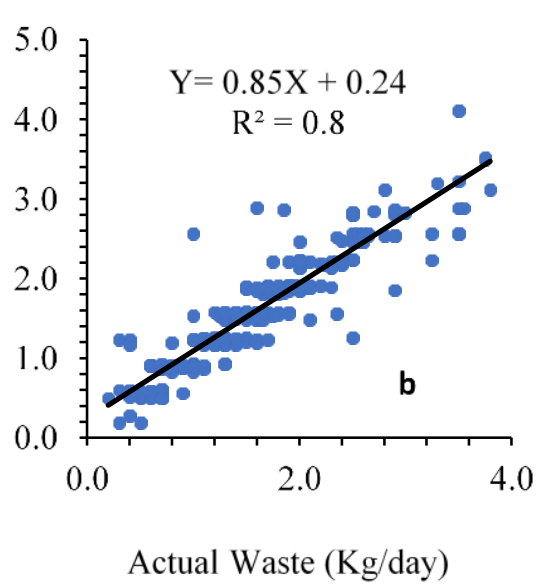

Actual Waste $(\mathrm{Kg} /$ day $)$

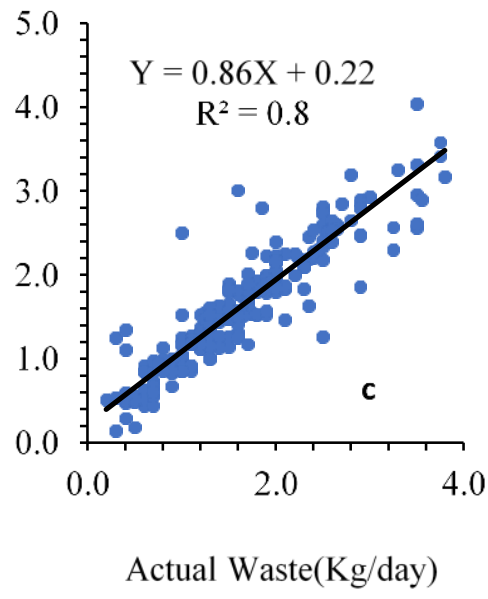

Figure 4: Correlation between actual household waste and predicated waste based on(a)household size, (b)income(c) Age, Income, and education

Although educated people should be progressive and mindful of waste's effect on conditions, the results do not show any significant effect. Therefore, the education level does not explicitly teach or make individuals mindful enough about waste's effect on the environment

In contrast, a study by Oribe-Garcia, Kamara-Esteban [62] indicated that educated people were more aware of the impact of waste on the environment. The difference can be explained by the slower waste generation rate at which such awareness increases compared with the rate for an uneducated person. High income people in Kathmandu have changed their eating habits. They usually eat in restaurants rather than cooking at home. It was expected that high salary people would spend more time outside their home thus creating less household waste than homemakers and retirees. The latter have more opportunity to make their own dinner instead of purchasing packaged food like high salary people.

A study by Maskey and Singh [19] indicated that waste generation is high in a house having diverse occupations; the stay-at-home members compensate for waste generation on behalf of those whose occupation requires more time outside the home. Waste generation in the study area was the outcome of the combined activities of all family members.

\section{Model Validation}

In this study, of the sample of 288 households, $10 \%$ were used for model validation. As can be seen in figure 5, $82.67 \%$ of total variation in HH waste generation per day HHs was accounted for by the four independent variables in the model. This confirms the model's validity. 


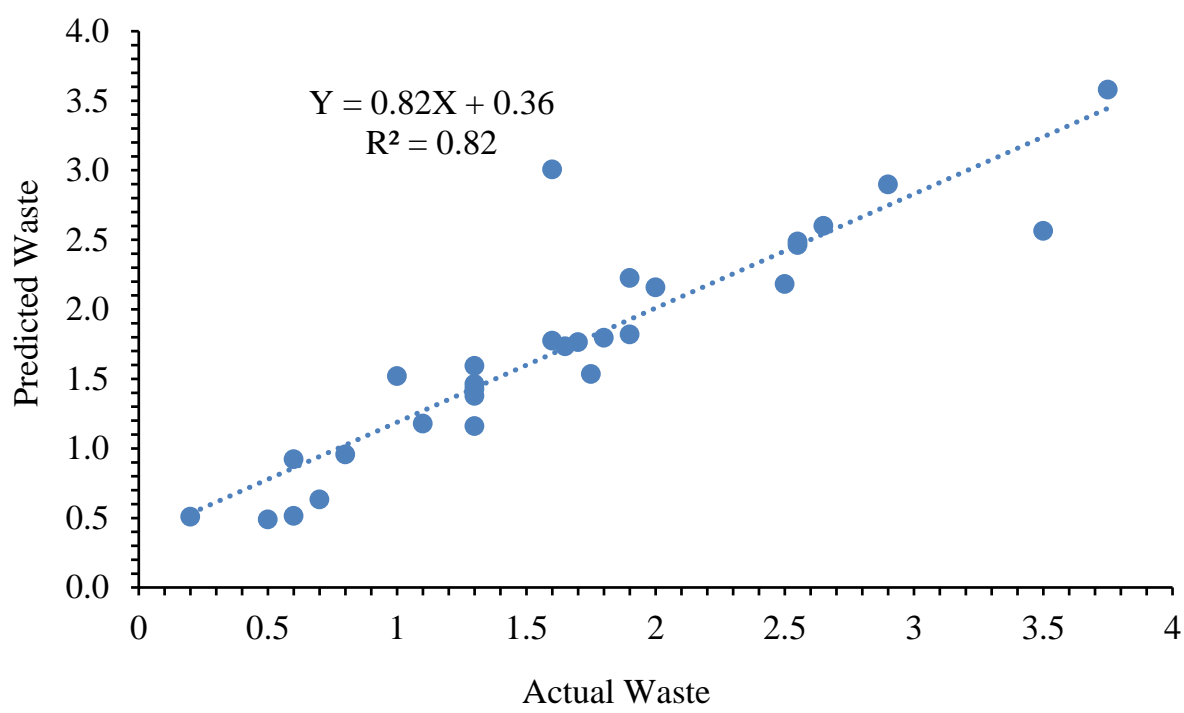

Figure 5: The predicted and actual waste generation (kg/capita/day) for model validation

\section{Waste Composition}

Household waste's composition in KMC is shown in Figure 6. It shows that organic waste is the largest fraction (51\%), followed by plastic (19\%) and textiles (13\%). Paper, rubber and leather, glass, metal, and other inert wastes range between $1 \%$ and $5 \%$ of the total waste. The results agree with previous studies conducted in Nepal [17] and reflect the general organic waste proportion in developing countries [3].

The high organic waste component means that the waste requires frequent collection and removal from its source (Asian Development Bank, 2013) because of its fast decomposition character. Inorganic waste, comprising $49 \%$ of total MSW, can be reused and recycled in some circumstances by a waste recovery process. The rest of the waste has to go landfill in the case of Kathmandu. It was very good to see that the use of plastic and paper has been expanding; they have currently become essential materials in everyday life especially for packaging. The use of plastic has increased from 5.4\% in 2005 to $12 \%$ in 2007 [24] and to $22 \%$ in 2013 [17]. The rapid increase in use of plastic might be because of its versatility and functionality including light weight, durability and cost effectiveness. The proportion of paper has also increased but in a steady, gradual way [63]. 


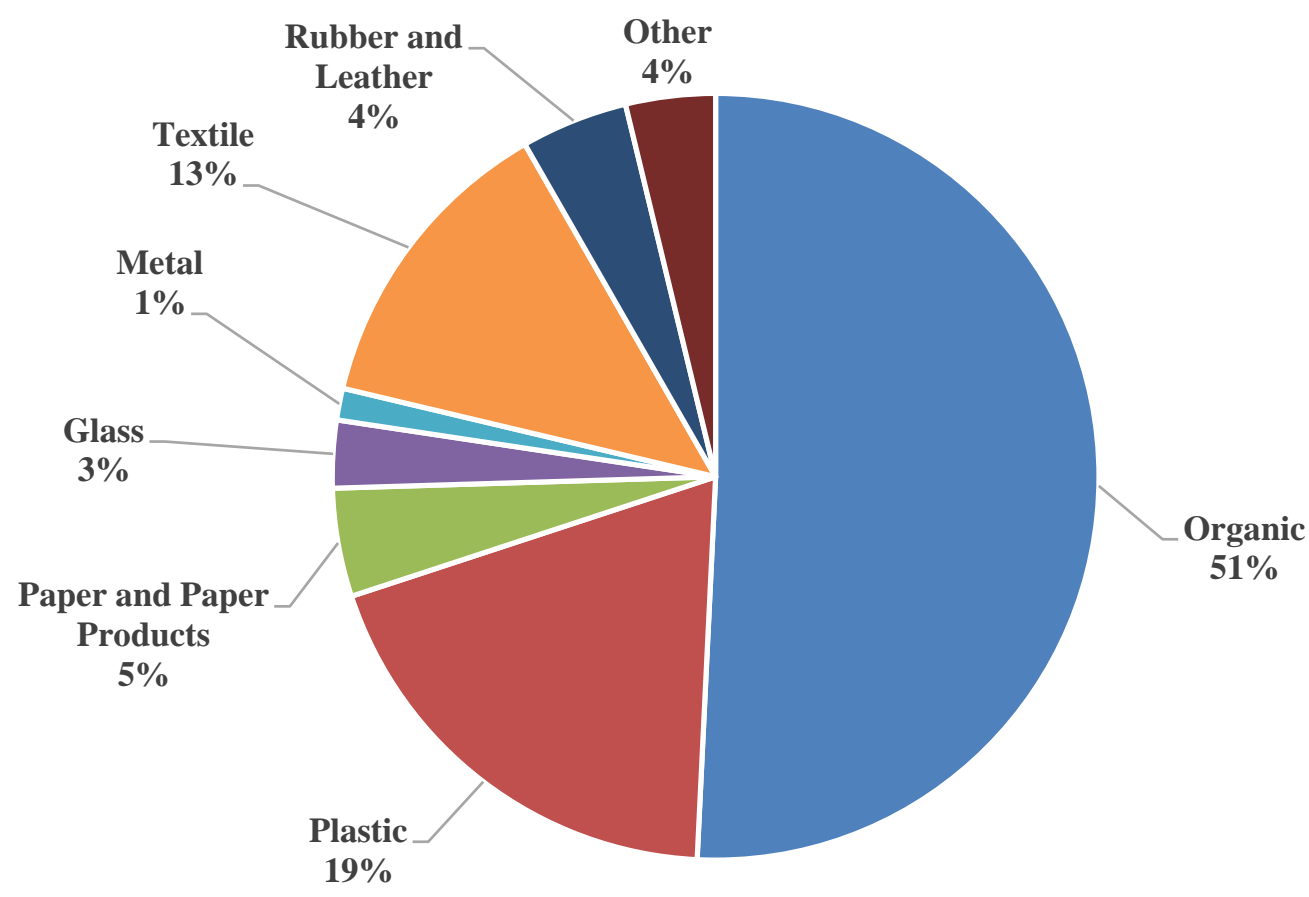

Figure 6: The composition of solid waste of Kathmandu City (\%)

With the increasing development works and the construction of new infrastructure, a different kind of waste has emerged in Kathmandu, construction debris. However, construction and demolition waste are not collected by the waste management service and are usually used again directly as construction material.

Currently, mixed waste generated within KMC is directly disposed to the Sisdole landfill site $28 \mathrm{~km}$ from Teku Transfer Station. If all the waste generated is collected and managed by the municipality, the total waste generated by each household would be about 150,745 tonnes/year. Assuming $51 \%$ of this is organic waste, about 76,879 tonnes/year of organic waste would be generated. This organic waste, when decomposed in the Sisdole landfill, produces methane that, on a weight basis has 21 times the global warming potential (GWP) of carbon dioxide [64]. Landfill sites are identified as the largest source of $\mathrm{CH} 4$ emissions from the solid waste sector [65]. At the Sisdole site, scavengers pick up recyclable waste to sell it to scrap dealers. However, there are no data to determine the recycling rate.

\section{CONCLUSION}

This study This study was based on household survey of 288 families selected using stratified sampling method from the 32 metropolitan wards of Kathmandu Metropolitan City (KMC), Nepal. The amount of the waste generated in KMC was $0.3 \mathrm{~kg} / \mathrm{person} /$ day and total household waste generation was found 413 tonnes/day. Household waste comprised of 51\% organic, $49 \%$ recyclable comprising 5\% paper and paper products, $3 \%$ glass, $1 \%$ metal, $19 \%$ plastic, $13 \%$ textiles, $4 \%$ rubber and leather and $4 \%$ other waste.

Socio-economic variables affecting household waste generation were analysis by using regression model. The result shows that family's size and income impact positively on waste generation. Therefore, these parameters can be used in forecasting household waste generation. Education, age did not have significant impact on waste generation.

Ninety two percent of the respondent reported that they are paying waste management tariff and are willing to segregate organic waste however currently total waste is disposed to landfill site without segregation due to lack of composting facilities. Therefore, concerning agency should take immediate steps to established organic waste management facilities such as composting plant or amoebic digitation plant, which will help to reduce landfill waste volume and thus increasing landfill life span. Finding from this study will be important sources of information. Organic waste has the most attractive option but if not overseen appropriately, it creates serious health and environmental hazards. It could be used productively by composting at the household and neighborhood government level. 


\section{ACKNOWLEDGMENT}

The authors would like to acknowledge funding sources provided by Lincoln University to support this study. Equally we would like to acknowledge the support from Kathmandu Metropolitan City, Nepal, and Solid Waste Management Section, Teku Kathmandu, Nepal.

\section{REFERENCES}

[1] Thenabadu, M., et al., Anaerobic Digestion of Food and Market Waste; Waste characterisation and Bio-methane Potential: A Case study in Sri Lanka. Sri Lanka energy managers association, 2014. 23: p. 29.

[2] Sankoh, F.P., X. Yan, and A.M.H. Conteh, A situational assessment of socioeconomic factors affecting solid waste generation and composition in Freetown, Sierra Leone. Journal of Environmental Protection, 2012. 2012.

[3] Hoornweg, D. and P. Bhada-Tata, What a waste: a global review of solid waste management. Urban development series knowledge papers, 2012. 15 : p. 1-98.

[4] Trang, P.T.T., et al., The effects of socio-economic factors on household solid waste generation and composition: a case study in Thu Dau Mot, Vietnam. Energy Procedia, 2017. 107: p. 253-258.

[5] Bandara, N.J., et al., Relation of waste generation and composition to socio-economic factors: a case study. Environmental monitoring and assessment, 2007. 135(13): p. 31-39.

[6] Ogwueleka, T.C., Survey of household waste composition and quantities in Abuja, Nigeria. Resources, Conservation and Recycling, 2013.77 : p. 52-60.

[7] Yusof, M.B.M., et al., The role of socio-economic and cultural factors in municipal solid waste generation: a case study in Taman Perling, Johor Bahru. Jurnal Teknologi, 2002. 37(1): p. 55-64.

[8] Suthar, S. and P. Singh, Household solid waste generation and composition in different family size and socio-economic groups: A case study. Sustainable Cities and Society, 2015. 14: p. 56-63.

[9] Hwa, T., Overview of solid waste management in Asian Countries. Asian Productivity Organization, 2007.

[10] Af, S., Handbook on The Least Developed Country Category: Inclusion, Graduation and Special Support Measures Second Edition. 2015. United Nations Department of Economic and Social Affairs. Accessed in https://www.un.org/development/desa/dpad/wpcontent/uploads/sites/45/publication/2015cdphandbook.pdf

[11] Glawe, U., C. Visvanathan, and M. Alamgir. Solid waste management in least developed Asian countries-a comparative analysis. in International Conference on Integrated Solid Waste Management in Southeast Asian Cities. 2005.

[12] Shekdar, A.V., Sustainable solid waste management: an integrated approach for Asian countries. Waste management, 2009. 29(4): p. 1438-1448.

[13] Visvanathan, C., et al., Municipal solid waste management in Asia. Asian regional research program on environmental technology (ARRPET). Asian Institute of Technology publications. ISBN, 2004. 974: p. 417-258.

[14] Hoornweg, D. and P. Bhada-Tata, What a waste: a global review of solid waste management. Vol. 15. 2012: World Bank, Washington, DC.

[15] Pariatamby, A. and S. Fauziah, Sustainable 3R practice in the Asia and Pacific Regions: the challenges and issues, in Municipal Solid Waste Management in Asia and the Pacific Islands. 2014, Springer. p. 15-40.

[16] Nabegu, A.B., An analysis of municipal solid waste in Kano metropolis, Nigeria. Journal of Human Ecology, 2010. 31(2): p. 111-119.

[17] Asian Development Bank (ADB) (2013). Solid waste management in Nepal: Status and policy recommendations. Mandaluyong City, Philippines, Asian Development Bank. Accessed in https://www.adb.org/sites/default/files/publication/30366/solid-waste-managementnepal.pdf [Accessed 5 Dec. 2017]

[18] Yadav, P. and S. Samadder, A critical review of the life cycle assessment studies on solid waste management in Asian countries. Journal of Cleaner Production, 2018. 185: p. 492-515.

[19] Maskey, B. and M. Singh, Household Waste Generating Factors and Composition Study for Effective Management in Gorkha Municipality of Nepal. Journal of Sustainable Development, 2017. 10(6).

[20] Central Bureau of Statistics (CBS). (2015). Compendium of Environment Statistics Nepal 2015. Government of Nepal, National Planning Commission Secretariat, Kathmandu, Nepal.

[21] Pokhrel, D. and T. Viraraghavan, Municipal solid waste management in Nepal: practices and challenges. Waste Management, 2005. 25(5): p. 555-562.

[22] Anderzen, C. and V. Blees, Solid waste management in the city of Kathmandu, Nepal; Evaluation of the Vaxjo risk assessment model applied on Gokarna landfill site. Program of Environmental Engineering, Kalmar University. Program of Environmental Engineering, Kalmar University (Doctoral dissertation, Thesis), 2003.

[23] Central Bureau of Statistics (CBS). (2011a). National Population and Housing Census 2011. Government of Nepal, National Planning Commission Secretariat, Kathmandu, Nepal

[24] Dangi, M.B., et al., Municipal solid waste generation in Kathmandu, Nepal. Journal of environmental management, 2011. 92(1): p. $240-249$.

[25] Ministry of Science Technology and Environment, Nepal Second National Communication. Prepared for the United Nations Framework Convention on Climate Change (UNFCCC). Ministry of Science, Technology and Environment, Singhadarbar, Kathmandu, Nepal. Available at:https://unfccc.int/resource/docs/natc/nplnc2.pdf. 2014.

[26] Dahal, I. P. (2015). a study of community participation in solid waste management in Kathmandu metropolitan city. Kathmandu, Nepal

[27] Alam, R., et al., Generation, storage, collection and transportation of municipal solid waste: A case study in the city of Kathmandu, capital of Nepal, in Waste Management. 2006.

[28] SWMRM, (2004). Solid Waste Management in Kathmandu Metropolitan City, Solid Waste Management and Resources Mobilization (SWMRM) 2004, Lalitpur Pulchowk, Nepal

[29] Disaster Risk Management Profile (DRMP). (2005). Kathmandu Valley, Disaster Risk Management Profile 23p. Government of Nepal Earthquakes and Megacities Initiative (EMI), Kathmandu, Nepal.

[30] Pant, P.R. and D. Dangol, Kathmandu valley profile. Briefing Paper, Governance and Infrastructure Development Challenges in Kathmandu Valley, 2009.

[31] Silwal, S., Waste to Energy: Solution for Municipal Solid Waste Management in Kathmandu Metropolitan City (KMC). 2019, University of Twente.

[32] Central Bureau of Statistics (CBS). (2011b). Statistical Yearbook of Nepal: Government of Nepal, National Planning Commission Secretariat, Kathmandu, Nepal.

[33] Central Bureau of Statistics (CBS). (2014). Population Monograph of Nepal. Government of Nepal, National Planning Commission Secretariat, Kathmandu, Nepal. 
[34] 3Maskey, B., K.L. MAHARJAN, and M. SINGH, Ecological solid waste management act and factors influencing solid waste management in barangay Pansol of Quezon City, the Philippines. Journal of International Development and Cooperation, 2016. 22: p. 37-45.

[35] Baum, H., Chandonnet, A., Fentress, J., \& Rasinowich, C., \&. (2012). Mixed-mode methods for conducting survey research: Data Recognition Corporation Minnesota, USA..

[36] Grande, T. (2016). Calculating the Sample Size with a Finite Population in Excel. YouTube. Retrieved July volume 19 pages 2019.

[37] Liu, J., et al., The Impact of consumption patterns on the generation of municipal solid waste in China: evidences from provincial data. International journal of environmental research and public health, 2019. 16(10): p. 1717.

[38] Mazzanti, M., A. Montini, and R. Zoboli, Municipal waste generation and socioeconomic drivers: Evidence from comparing Northern and Southern Italy. The Journal of Environment \& Development, 2008. 17(1): p. 51-69.

[39] Thanh, N.P., Y. Matsui, and T. Fujiwara, Household solid waste generation and characteristic in a Mekong Delta city, Vietnam. Journal of Environmental Management, 2010. 91(11): p. 2307-2321.

[40] Bureecam, C. and T. Chaisomphob, Models of municipal solid waste generation and collection costs applicable to all municipalities in Thailand. Songklanakarin Journal of Science \& Technology, 2015. 37(4).

[41] Jenkins, R.R., The economics of solid waste reduction. Books, 1993.

[42] Cailas, M., et al., Development and application of a comprehensive approach for estimating solid waste generation in Illinois: first phase results. Urbana, ILL: The Center for Solid Waste management and Research University of Illinois Urbana-Champaign, 1993.

[43] Rhyner, C., et al., Domestic solid waste and household characteristics. Waste Age, 1976. 7(50): p. 29-30.

[44] Kayode, A. and F. Omole, Some socio-economic factors affecting solid wastes generation and disposal in Ibadan metropolis, Nigeria. Journal of environmental issues and agriculture in developing countries, 2011.3(1): p. 55-64.

[45] Richardson, R.A. and J. Havlicek Jr, Economic analysis of the composition of household solid wastes. Journal of environmental economics and management, 1978. 5(1): p. 103-111.

[46] Monavari, S.M., et al., The effects of socioeconomic parameters on household solid-waste generation and composition in developing countries (a case study: Ahvaz, Iran). Environmental monitoring and assessment, 2012. 184(4): p. 1841-1846.

[47] Duggal, V.G., C. Saltzman, and M.L. Williams, Recycling: an economic analysis. Eastern economic journal, 1991. 17(3): p. $351-358$.

[48] Reschovsky, J.D. and S.E. Stone, Market incentives to encourage household waste recycling: Paying for what you throw away. Journal of policy analysis and management, 1994. 13(1): p. 120-139.

[49] Jenkins, R.R., et al., The determinants of household recycling: a material-specific analysis of recycling program features and unit pricing. Journal of environmental economics and management, 2003. 45(2): p. 294-318.

[50] Ferrara, I. and P. Missios, Recycling and waste diversion effectiveness: evidence from Canada. Environmental and Resource Economics, 2005. 30 (2): p. 221-238.

[51] Callan, S.J. and J.M. Thomas, Analyzing demand for disposal and recycling services: a systems approach. Eastern Economic Journal, 2006. 32(2): p. 221-240.

[52] Sujauddin, M., S. Huda, and A.R. Hoque, Household solid waste characteristics and management in Chittagong, Bangladesh. Waste management, 2008. 28(9): p. 1688-1695.

[53] Afroz, R., K. Hanaki, and R. Tudin, Factors affecting waste generation: a study in a waste management program in Dhaka City, Bangladesh. Environmental monitoring and assessment, 2011. 179(1-4): p. 509-519.

[54] Johnstone, N. and J. Labonne, Generation of household solid waste in OECD countries: an empirical analysis using macroeconomic data. Land Economics, 2004. 80(4): p. 529-538.

[55] Allison, P. D. (1999). Multiple regression: A primer: Pine Forge Press. Series in research Method and statistics. Sage Publications Ltd, 6 Bonhill Street, London EC2A 4PU.

[56] Safa, M., K.C. Birendra, and M. Safa, Linear model to predict energy consumption using historical data from cold stores. 2015.

[57] Gregoire, T.G. and M.R. Reynolds, Accuracy testing and estimation alternatives. Forest science, 1988. 34(2): p. 302-320.

[58] Chen, W., et al., Model validation via uncertainty propagation and data transformations. AIAA journal, 2004. 42(7): p. $1406-1415$.

[59] Fakruddin, M., R.M. Mazumder, and K.S.B. Mannan, Predictive microbiology: modeling microbial responses in food. Ceylon J. Sci, $2011.40(2)$ : p. $121-131$.

[60] Kaza, S., et al., What a waste 2.0: a global snapshot of solid waste management to 2050. 2018: The World Bank.

[61] Afroz, R., et al., Survey and analysis of public knowledge, awareness and willingness to pay in Kuala Lumpur, Malaysia-a case study on household WEEE management. Journal of Cleaner Production, 2013. 52: p. 185-193.

[62] 62. Oribe-Garcia, I., et al., Identification of influencing municipal characteristics regarding household waste generation and their forecasting ability in Biscay. Waste management, 2015. 39: p. 26-34.

[63] UDM, (2015). Solid Waste Management of Kathmandu Metropolitan City, Environmental Audit Report,2015, Urban Development Ministry (UDM) ,Singh Durbar, Kathmandu, Nepal

[64] EPA. (2011). Available and Emerging Technologies for Reducing Greenhouse Gas Emissions from Municipal Solid Waste Landfills. Environmental Protection Agency (EPA) office Of Air Radiation, North Carolina 27711, United State.

[65] UNEP, \&. (2010). Waste and climate change: Global trends and strategy framework: United Nations Environment Programme Nairobi. 


\section{AUTHORS}

First Author - Raju Khadka, PhD Student, Department Land Management and Systems Lincoln University, Christchurch,

New Zealand and raj.khadka@ lincolnuni.ac.nz

Second Author - Majeed Safa, Senior Lecture, Department Land Management and Systems Lincoln University, Christchurch, New Zealand Majeed.Safa@lincoln.ac.nz

Third Author - Alison Bailey, Professor, Department Land Management and Systems Lincoln University, Christchurch, New Zealand Alison.Bailey@lincoln.ac.nz

Fourth Author - Birendra KC, Civil Engineer, Aqualinc Research Limited, Christchurch, New Zealand and birendra@aqualinc.co.nz

Fifth Author - Raju Poudel, Civil Engineer, Vyas Municipality Office, Tanahun, Nepal and er.razoo@gmail.com

Correspondence Author - Raju Khadka, raj.khadka@lincolnuni.ac.nz, raj119us@ gmail.com. Mob; -+642102467906. 